\section{Scientific boycott of South Africa}

SIR-Whatever the merits of the original article on the boycott of South Africa that appeared in Nature, the path advocated in the polemic of J.G. Wilson (Nature 328,288 ; 1987) would ensure that the Nationalist government remained in power for at least another four decades.

South Africans have been subjected to boycotts for long enough now for a reasonable evaluation to be made of the effects. The sports boycott is generally assumed by the international community to have been successful in changing government policy to interracial sport. It has also now convinced voting South Africans that any such reforms will not produce a positive response from the international community, and has removed the incentive for reform in other areas. Similarly, the oil and arms boycotts have resulted only in South Africa now being partly self-sufficient in these commodities and more immune to international action. The outcome of the South African elections is convincing evidence that the current flurry of disinvestment has not forced a change for the better in attitudes.

Recent history has shown clearly enough that the Nationalist government wields its power through education and economics. Change can be wrought only through altering the balance of this power in favour of the black population. The change in education could be achieved only by a massive investment in black education, particularly in teacher training. At the moment, there are not enough teachers and facilities to provide even a primary education to all black children. This has serious consequences for institutions such as the University of Cape Town where efforts to increase the number of black students admitted, despite government opposition, may be thwarted because of the inadequacies of the school system.

Education cannot be separated from economics; so much is clear from the British experience. As with other areas of South African life, black education suffers most when the economy is in decline. In addition, black labour was not well organized previously because black trades unions were illegal. Now that they are legal, the international community is ensuring their ineffectiveness by attempting to destroy their economic base through boycotts. Rising unemployment and rising illiteracy do nothing for the growth of power amongst the disenfranchised. Arguments that their lot could not get worse ignore reality. If you cannot afford bread, you certainly cannot afford books.

The solution is simple, if radical: a massive investment in the South African economy. No doubt this will help the rich, but that is a small price to pay for the crucial benefits it would have for the growth in the economy and education of the underprivileged and disenfranchised people of South Africa. An investment in South Africa is an investment in the possibility of a nonracial future. Disinvestment simply gives the Nationalist government a licence to continue in power, a message reinforced by the results the South African election.

Voting South Africans have lived under threats and sanctions for a great many years now and have learned to live with them. They also see a certain inequality between the international treatment of South Africa and that of other nondemocratic states, which translates into further hardening of attitudes. An informal academic boycott has been in progress for some time and the efforts to formalize it cannot be expected to coerce a president who never went to a university, and will have little impact on the voting public. Communication is a quintessential facet of science and of academic research in general. Threats have not changed attitudes for the better, so why not at least apply the principle of communication to South Africans of whatever colour or persuasion?

University College,

Oxford $O X 14 B H, U K$

SiR-The fact that J.G. Wilson (Nature 328,$288 ; 1987$ ) did not like what he read in John Maddox's report of his visit to South Africa does not make Maddox ipso facto a racist, nor is the anti-apartheid cause furthered by a passionate misrepresentation of facts.

Far from young South African blacks being denied an education or careers in science, every effort is being made to encourage them to enter the science and engineering fields. Reflecting changes taking place, over the past two to three years the majority of winners of the South African Science Olympiad, a competition for pupils in their last two years of school, have been blacks. The Council for Scientific and Industrial Research tries to stimulate an interest in science careers by arranging visits of black and white schoolleavers to its research laboratories, offers bursaries for both undergraduate and postgraduate study, and posts in research institutes on graduation on an equalopportunity basis. Some large companies specifically sponsor black students on science and engineering courses at university, with guaranteed employment, again on an equal-opportunity basis, on completion of studies.

Rather than promoting a policy that would remove such backing and destroy jobs, or cause a mass exodus from South
Africa (where to and financed by whom?), surely a constructive action would be to build on the change which is taking place whether Wilson likes it or not. If he does have any real concern for black South Africans, Wilson could for one thing direct his energies towards compaigning for funds desperately required to build the one school a day until the year 2000 needed to keep pace with rapid population growth, thus ensuring the important role of blacks in science in the South Africa of the future.

Peggy Beezhold

35 Kensington Court

London W8, UK

SIR-There was one major omission from your review of South African science (Nature 327, 269; 1987), which was the effect of the financial crisis, particularly the steep devaluation of a couple of years ago, on the funding situation. Political and social problems are, in the long run, probably the decisive ones, but in the short run, views of them are very subjective. There is nothing subjective about the financial situation.

For people like myself, who had intended to return to the United Kingdom on retirement, the exchange rate is nothing short of disastrous. For those who have no contacts outside South Africa, and therefore depend only on internal finance, the effect can be quite small. For scientists in general, who must obtain books and scientific supplies from overseas, or who depend on anything imported, the effect is very serious.

You discuss the effect of possible sanctions on the supply of journals. It seems to us at present much more likely that scientific journals will be priced right out of our reach than that they will be politically impossible to obtain.

On the personal level, selling a fairly large house in Durban is likely to provide enough funds to buy only a very moderately sized car in the United Kingdom. Indeed, my house cost me about $£ 15,000$ when I came here 15 years ago, and I expect to get about the same for it now.

It would be interesting to know who was the American who got $\mathrm{R} 75,000$ working for the Council for Scientific and Industrial Research. I thought that in the public service only politicians got anything like that pay. University staff certainly do not.

Department of Chemistry David A. H. TAYLOR

and Applied Chemistry, University of Natal,

King George V Avenue,

Durban 4001.

South Africa

Letters submitted for Correspondence should be typed, double-spaced, on one side of the paper only. 